\title{
Investigation of Neurologic Complications in Closed Wedge High Tibial Valgization Osteotomy Technique by Using Electrophysiological Methods
}

\author{
Kapalı Kama Yüksek Tibial Valgizasyon Osteotomi Tekniği Nörolojik Komplikasyonlarının \\ Elektrofizyolojik Yöntemle Araştırılması
}

\author{
Bülent Yücel1', Serhat Mutlu1', Baran Kömür1, Harun Mutlu², Ömer Özel³, Rıfat Erginer ${ }^{4}$ \\ ${ }^{1}$ Clinic of Orthopedics and Traumatology, Kanuni Sultan Süleyman Training and Research Hospital, İstanbul, Turkey \\ ${ }^{2}$ Clinic of Orthopedics and Traumatology, Taksim Training and Research Hospital, İstanbul, Turkey \\ ${ }^{3}$ Department of Orthopedics and Traumatology, Başkent University, İstanbul, Turkey \\ ${ }^{4}$ Department of Orthopedics and Traumatology, İstanbul University Cerrahpaşa Faculty of Medicine, İstanbul, Turkey
}

\begin{abstract}
Objective: The aim of this study is to investigate neurologic complications of closed wedge valgization osteotomy technique using electrophysiological methods.

Methods: Eleven extremities of 11 patients (mean age 52.75 \pm 5.39 ) with medial gonarthrosis and varus deformity were included. All patients underwent closed wedge valgization osteotomy in order to correct varus deformity.

Results: The post-operative amplitude of nervus peroneus superficialis significantly decreased when compared to pre-operative amplitude. The mean pre-operative $N$. peroneus superficialis amplitude was 12.77, whereas it reduced to 5.44 postoperatively $(p<0.05)$. Other nerve conduction velocity investigations showed no significant differences between pre- and post-operative values. A Needle Electromyography (EMG) study demonstrated neurogenic involvement in 4 patients after surgery. All of these 4 patients had denervation in the m.extensor hallucis longus needle EMG study. In 2 patients, the musculus tibialis anterior needle EMG study showed neurogenic involvement. One of these had denervation. One patient showed denervation in the m.extensor digitorum brevis needle EMG study.
\end{abstract}

Conclusion: Although fibula osteotomy used in the closed wedge osteotomy technique was applied from the safe zone, electrophysiological investigations suggested that this zone may, in fact, not be safe. (JAREM 2014; 1: 12-7)

Key Words: Closed wedge, high tibial osteotomy, valgization osteotomy, peroneal nevre

\section{ÖZET}

Amaç: Bu çalışmanın amacı kapalı kama valgizasyon osteotomisi tekniğinin nörolojik komplikasyonlarını elektrofizyolojik yöntemlerle araştırmaktır. Yöntemler: Ortalama yaşları 52,75 ( $\pm 5,39)$ olan varus deformitesi bulunan medial gonartrozlu 11 hastanın 11 ekstremitesi çalışmaya alınarak mevcut varus deformitelerini düzeltme amacıyla uygulanan kapalı kama valgizasyon osteotomisi uygulanan hasta grubu çalışmaya dahil edilmiştir.

Bulgular: Nervus peroneus süperfisialis amplitüdü incelendiğinde ameliyat öncesine göre ameliyat sonrası ortalama olarak anlamlı şekilde azalma saptanmıştır. Ameliyat öncesi ortalama N. peroneus süperfisialis amplitüdü 12,77 iken ameliyat sonrası ortalama değer 5,44 olarak bulunmuştur ( $p<0,05$ ). Diğer sinir ileti hızları incelemelerinde ise ameliyat öncesi ve sonrası arasında istatiksel olarak anlamlı fark saptanmamıştır.

Iğne Elektromyografi (EMG) çalışmasında ise 4 hastada ameliyat sonrası incelemede nörojen tutulum saptanmıştır. Dört hastanın tamamında m. ekstansör hallusis longus iğne EMG çalışmasında denervasyon saptanmıştır. İki hastanın musculus tibialis anterior iğne EMG çalışmasında nörojen tutulum saptanmıştır. Bunlardan birinde denervasyon saptanmıştır. Bir hastada m. ekstansör dijitorum brevis iğne EMG çalışmasında denervasyon saptanmıştır.

Sonuç: Kapalı kama osteotomi tekniğinde kullanılan fibula osteotomisi güvenli bölgeden yapılmasına rağmen elektrofizyolojik inceleme sonuçları bu bölgenin güvenli olduğu konusunda şüphe uyandırmaktadır. (JAREM 2014; 1: 12-7)

Anahtar Sözcükler: Kapalı kama, yüksek tibial osteotomi, valgizasyon ostetomisi, peroneal sinir

\section{INTRODUCTION}

Currently, although arthroplasty is prevalent in the treatment of gonarthrosis, high tibial osteotomy (HTO) in the treatment of young patients still maintains its importance. However, as in the other knee surgeries, HTO has complications. Complications related with peroneal nerve especially are among the important complications of the technique (1). In our study, we aimed to investigate the peroneal nerve complications by using electrophysiological methods in patients who underwent HTO with the closed wedge valgization technique. The reason for using elec- trophysiological examination in the study is to determine peroneal nerve lesions without clinical signs or symptoms.

In the literature, in a study conducted on thirty cadaveric legs, the innervation of m.extensor hallucis longus was examined. The muscle was innervated by only one branch of n.peronealis profundus in twenty seven (90\%) cases, and by 2 branches of the nerve in only $3(10 \%)$ cases. The nerve penetrated the muscle from the fibular side in twenty one cases, from the tibial side in 6 cases and from the anterior aspect in 6 cases. The nerve following the fibular route was extending very close to fibular periosteum (3). 
Patient selection is one of the most important factors affecting the success of high tibial osteotomy. In the last 15 years, patient selection criteria for HTO have become more limited in parallel with developments in total knee arthroplasty. Despite successful results, due to activity limitations in the post-operative period of total arthroplasties and limited life of prosthesis, osteotomy seems to be the most convenient intervention in young and active patients with single compartment arthritis.

At present, the indications for osteotomy and prosthesis are not clearly defined and intervention is shaped by the personal evaluation criteria of patient and surgeon. In these criteria, the patient should be evaluated as a whole, not only the knee.

\section{METHODS}

Our study was planned on the patients with medial gonarthrosis and varus deformities between April 2002 and April 2004. Preoperatively, all patients signed consent forms for surgery.

\section{Surgical Technique}

In all patients of our series, lateral closed wedge valgization osteotomy was applied. After the patient was taken to a standard operation table, anesthesia was achieved by using one of the general or spinal anesthesia techniques and a pneumatic tourniquet was applied to the lower extremity. Knee joint compartments were evaluated by arthroscopy before osteotomy. The fibular head, gerdi tubercleand tuberositas tibia were determined and an oblique incision was made from the fibular head to the tuberositas tibia. Subdermal tissue was passed (Figure 1). The anterior part of the osteotomy area was exposed by removing the anterior retinaculum from the lateral rim of the patellar tendon by sharp dissection, and extensor muscles were detached subperiostally from the tibia metaphysis. Attachment sites of tibialis anterior were scraped in distal and lateral directions. The lateral tibial metaphysis was completely exposed for osteotomy. To do this, a homan retractor was placed onto the posterior tibia by scraping the periosteum. The proximal part of the osteotomy was cut by a chisel from lateral to medial, $2-2.5 \mathrm{~cm}$ distal to the joint, and parallel to the K-wire guide inserted into the knee joint. Then, the height of the wedge was calculated and the distal border determined. The distal border of osteotomy was cut from lateral to medial and from distal to proximal by guidance of a ruler placed on the first osteotomy line. Thus the two osteotomy lines combined in the medial site. Both rims of the osteotomy were made deeper with the help of a thin and wide osteotom, but the medial cortex was kept intact and the wedge was removed. Then, a 5-cm longitudinal incision was made from the lateral cruris $16 \mathrm{~cm}$ distal to the fibular head. After passing through skin and subdermal structures, the fibula was exposed by blunt dissection among the fibers of $\mathrm{m}$. peroneus longus. 2 retractors with round shaped endings were placed around the fibula by scraping the periosteum. Then, a 1-2 cm bone block was removed using a motor saw, and the intact medial cortex of the tibia was used as a hinge, and the knee was forced into valgus and theosteotomy area was closed. After controlling the alignment of the knee, two deep stepped " $U$ " staple and one smooth " $U$ " staple were used for internal fixation (Figure 2). In case of " $U$ " staple absence, or in cases who were planned for bilateral operation, rigid fixation were made by a half $\mathrm{T}$ plate. In total, two drains were placed: one for the tibia osteotomy area and one for the fibular osteotomy area. All layers were closed according to anatomy and a Jones bandage was applied (Figure 3). Evaluation was made by postoperative radiography (Figure 4).

\section{Radiological and Clinical Method}

Preoperative orthoroentgenograms are used to measure mechanical axis, anatomical axis 1 and 2, mechanical axis deviation, proximal medial tibial angle, distal lateral femoral angle, knee joint converggence angle and ankle adaptation angle in all patients. Then, the above-mentioned closed wedge valgization HTO operation was made. Patients were followed up at hospital services after surgery. Of the 20 patients who were operated by the closed wedge valgization $\mathrm{HTO}$ and $U$ staple fixation method, 11 patients younger than 60 years and without peripheral neuropathy were included in the study. In total, 15 extremities were

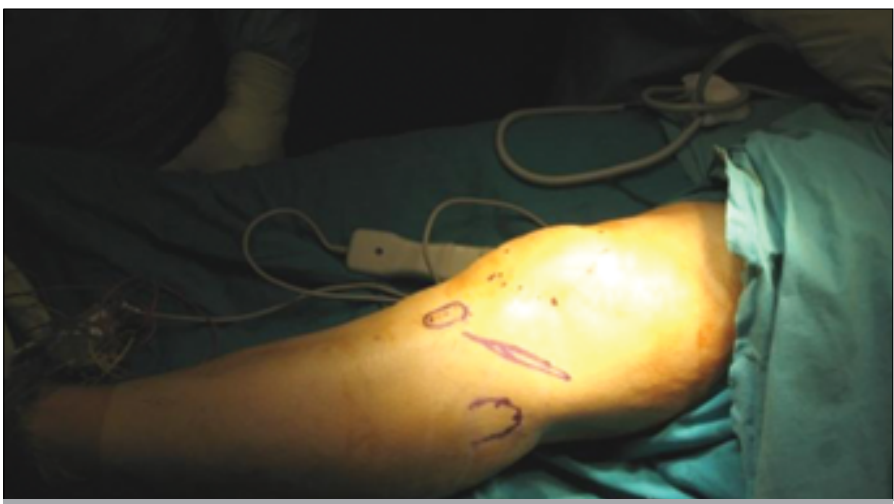

Figure 1. Pre-operative preparation and incision

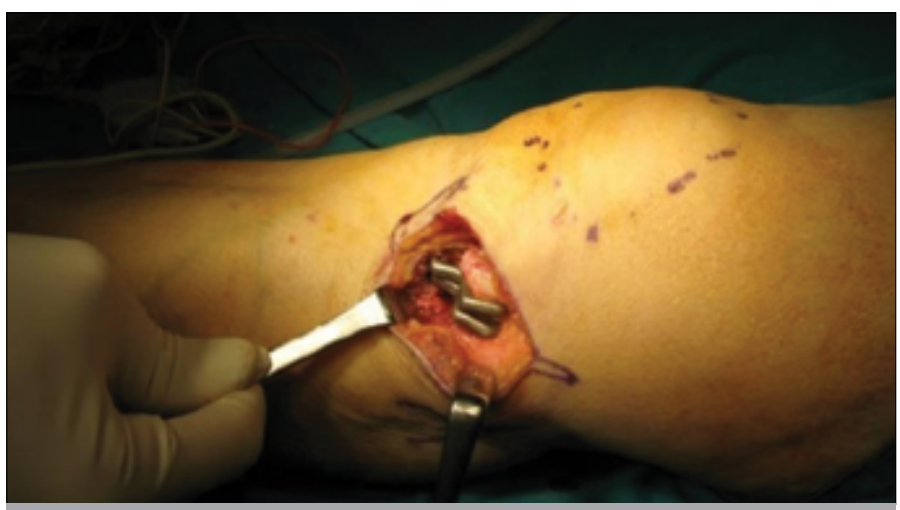

Figure 2. Closing and fixation of osteotomy line

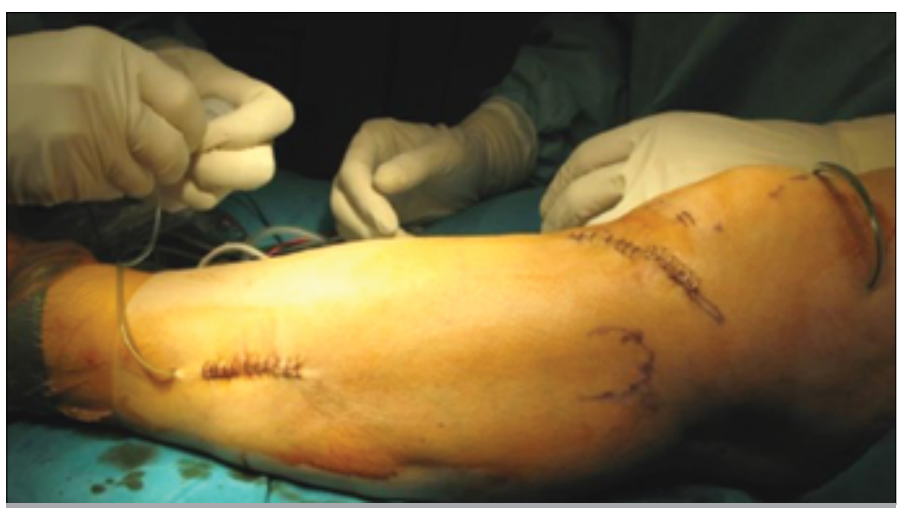

Figure 3. Closing incisions 


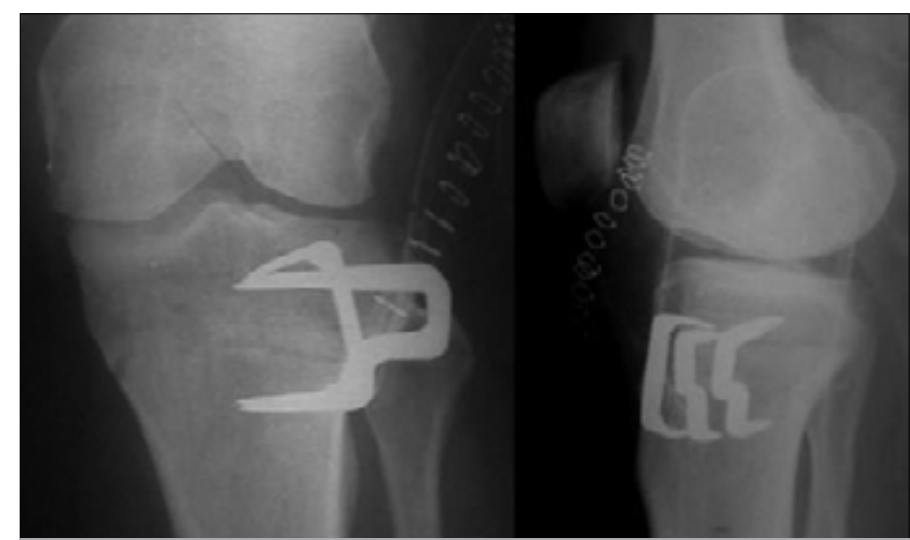

Figure 4. Radiographic evaluation after surgery

operated. Four patients had operations on both sides at different sessions and 7 patients had an operation on a single side. In the patients who had bilateral operations, only one extremity was evaluated. The mean age of the patients was $52.75( \pm 5.39)$ years. All patients underwent electrophysiological investigation 1-day before the operation. In this investigation, the unoperated side served as control for the operated side.

\section{Electrophysiological Method}

Electrophysiological investigations of the patients were made at the EMG laboratory by using the Nihon-Kohden Neuropack 2 device. Needle EMG investigations for motor and sensory nerve conduction velocities of patients were performed before the HTO operation and 2 months after the operation in both lower extremities.

The inter-electrode distance was $25 \mathrm{~mm}$ during motor and sensory nerve conduction velocity assessments. Supramaximal electrical stimulation was made with a superficial stimulator at 0,2 msec durations. In the investigation of motor conduction velocity, both peroneal nerves were stimulated at the ankle, fibular head, and 80-100 mm proximal to the fibular head. Latency and amplitude values of motor unit potentials (MUP) in the extensor digitorum brevis muscles were recorded. For MUP recordings, $6 \mathrm{~mm}$ diameter circular metal superficial electrodes were used.

In the investigation of sensory conduction velocity, both sural nerves were stimulated at $100-150 \mathrm{~mm}$ proximal to the lateral malleolus, and the latency and amplitude values of sensory potentials were recorded. Both superficial peroneal nerves were stimulated at the anterior border of the fibula $100-120 \mathrm{~mm}$ proximal to the lateral malleolus, and the latency and amplitude values were recorded. In the investigation of sensory conduction velocity, the distance between active and reference electrodes was $25 \mathrm{~mm}$, and $6 \mathrm{~mm}$ diameter round-shaped metal superficial electrodes were used. During motor and sensory conduction velocity assessments, a ground electrode was placed between the stimulator and recording electrodes.

Concentric needle electrodes were used for needle EMG and vastus medialis, tibialis anterior, extensor hallucis longus, extensor digitorum brevis, extensor digitorum longus and gastrocnemius muscles of both extremities were investigated.

\section{Statistical analysis}

All patients who completed the 2 months follow up period were re-evaluated for electrophysiological changes at the same poly- clinics by the same neurologist. The data obtained were transferred to SPSS (Statistical Package for the Social Sciences) 10.5 software and comparisons were made by paired samples t-test.

\section{RESULTS}

The amplitude of $N$. peroneus superficialis significantly reduced postoperatively when compared to preoperative values. The mean amplitude of $N$. peroneus superficialis before and after surgery were 12.77 and 5.44 respectively $(p<0.05)$. When operated and unoperated sides were compared in terms of $n$. peroneus superficialis amplitude, the amplitude of the operated side was significantly lower. The amplitude of $\mathrm{n}$. peroneus superficialis was 15.27 on the unoperated side, whereas it was 5.44 on the operated side $(p<0.05)$. In the nerve conduction velocity study, the nerve conduction velocity of $N$. peroneus superficialis was normal. Thus, amplitude reduction was explained by axonal involvement.

There was no significant difference in pre- and post-operative distal latency of $N$. peroneus communis, distal conduction velocity of $N$. peroneus communis, proximal conduction velocity of $N$. peroneus communis, $N$. peroneus communis amplitude, n.suralis conduction velocity, n.suralis amplitude, and $N$. peroneus superficialis conduction velocity ( $p>0.05$ for all comparisons).

Pre- and post-operative nerve conduction velocities of the control group were comparable ( $p>0.05)$. In addition, there was no significant difference between pre- and post-operative nerve conduction velocities of the operated and unoperated sides ( $p>0.05)$.

The Needle EMG study revealed neurogenic involvement in 4 patients after surgery. All of these four patients showed denervation in the $m$. extensor hallucis longus needle EMG study (N. peroneus profundus). Two patients showed neurogenic involvement in the m. tibialis anterior needle EMG study. One of these had denervation. One patient showed denervation in the $\mathrm{m}$. extensor digitorum brevis needle EMG study. Results of nerve conduction velocity studies were given in Table 1.

There was no significant relationship between the ages of patients, the amount of wedge resection and electrophysiological investigation. In addition, there was no significant relationship between preoperative mechanical axis values and electrophysiological investigation results.

\section{DISCUSSION}

Peroneal nerve dysfunction is one of the important complications of knee surgery. The peroneal nerve complication rate is around $20 \%$ in the HTO operations. Peroneal nerve injury may be due to two factors in HTO operations: injury due to surgery and injury due to ischemia resulting from a tourniquet. Nebelung et al. (3) compared two methods of peroneal nerve conduction testing during surgery. The study aimed to investigate tourniquet-dependent nerve injury. Fibula osteotomy was applied from the fibular head after closed wedge osteotomy. Plate and staples were used to fix the osteotomy line. It is known that axonal conduction velocity of peripheral nerves is reduced under ischemic conditions. Excitability of nerve and reduction in conduction velocity totally recover when the ischemic time is under 10 minutes. How- 
Table 1. Statistical evaluation of nerve conduction velocities and amplitudes

\begin{tabular}{|c|c|c|c|c|c|}
\hline & \multicolumn{2}{|c|}{ Operated extremity (preop) } & \multicolumn{2}{|c|}{ Operated extremity (postop) } & \multirow[b]{2}{*}{$p$} \\
\hline & Mean & SD & Mean & SD & \\
\hline fibdg1 & 3.8400 & 0.4334 & 3.5382 & 1.2814 & 0.473 \\
\hline fibdg2 & 9.7036 & 0.6309 & 8.9418 & 3.0481 & 0.445 \\
\hline fibdg3 & 11.564 & 0.693 & 10.527 & 3.614 & 0.368 \\
\hline fibhdi & 48.591 & 3.226 & 42.527 & 14.280 & 0.174 \\
\hline fibhpr & 54.164 & 5.778 & 50.873 & 18.360 & 0.572 \\
\hline fibap1 & 4.2645 & 1.0793 & 3.8055 & 1.9440 & 0.328 \\
\hline fibap2 & 3.9736 & 1.1481 & 3.5391 & 1.9763 & 0.401 \\
\hline fibap3 & 3.739 & 1.149 & 3.485 & 1.788 & 0.613 \\
\hline slsrlh & 44.31 & 15.64 & 44.14 & 15.15 & 0.843 \\
\hline psph & 46.418 & 16.315 & 30.864 & 24.884 & 0.067 \\
\hline \multirow[t]{3}{*}{ pspamp } & 12.7736 & 7.3059 & 5.4427 & 5.5879 & $0.024^{*}$ \\
\hline & \multicolumn{2}{|c|}{ Unoperated extremity (preop) } & \multicolumn{2}{|c|}{ Unoperated extremity (postop) } & \\
\hline & Mean & SD & Mean & SD & $p$ \\
\hline fibdg1 & 3.9845 & 0.5467 & 3.5382 & 1.2814 & 0.311 \\
\hline fibdg2 & 9.5527 & 0.7297 & 8.9418 & 3.0481 & 0.528 \\
\hline fibdg3 & 11.335 & 0.803 & 10.527 & 3.614 & 0.474 \\
\hline Fibhdi & 50.055 & 3.078 & 42.527 & 14.280 & 0.097 \\
\hline Fibhpr & 56.545 & 4.365 & 50.873 & 18.360 & 0.354 \\
\hline fibap2 & 4.664 & 1.251 & 3.5391 & 1.9763 & 0.054 \\
\hline fibap3 & 4.539 & 1.274 & 3.485 & 1.788 & 0.058 \\
\hline srlh & 49.536 & 4.429 & 44.14 & 15.15 & 0.358 \\
\hline srlamp & 16.033 & 4.475 & 17.200 & 8.061 & 0.551 \\
\hline psph & 47.28 & 16.54 & 30.864 & 24.884 & 0.058 \\
\hline pspamp & 15.2709 & 9.5607 & 5.4427 & 5.5879 & $0.007^{\star \star *}$ \\
\hline
\end{tabular}

ever, because of long-tourniquet times in orthopedic surgery, there may be irreversible motor function loss which cannot be defined clinically (7).

In a study by Aydogdu et al. (1), peroneal nerve dysfunction after HTO was examined by electrophysiological methods in 11 patients. Pre- and post-operative EMG and nerve conduction velocity studies were performed. Pre-operative investigations were made 1 day before surgery, whereas post-operative invetigations were made 6 months after surgery. Maquet type HTO was applied to the patients. At the end of the study, there was a positive correlation between the degree of deformity and neurologic involvement. However, there was no significant relationship between the degree of deformity and neurologic involvement in our study (1). Three patients showed motor and/or sensory involvement of the peroneal nerve. Only 1 patient had clinical signs. Nerve conduction velocity was reduced in two patients with motor involvement. Sensory nerve conduction velocity was reduced in 2 patients. In 2 patients with motor involvement in the EMG examination, there was partial degeneration. Electrophysiological parameters could not be recorded in 2 patients due to lack of stimulation. In the literature, the rate of weakness in ankle and thumb extensors was 2 to $20 \%$ in patients who underwent HTO. Possible exlplanations included anterior tibial compartment syndrome, peroneal nerve injury, tibialis anterior artery injury and ischemia due to the tourniquet. We suggest that nerve injury mostly results from surgery because peroneal nerve and its branches extend very close to the area of surgery and peroneal nerve injury occurs mostly during fibular ostetomy. This is because of the partial character and distal location of the lesion. Recent anatomic studies pointed out osteotomy as the reason for peroneal nerve lesions. In osteotomies applied at the $1 / 3$ proximal part of the fibula, the risk of peroneal nerve injury is higher due to the close relationship between the bone and nerve. Nerve lesions can be seen even in the osteotomies applied in the so-called safe region (distal part). In our study, fibular osteotomy was applied in the safe zone, but electrophysiological investigations questionned the safety of this region. Thus, the safe zone is still debated.

There are few studies on the rate of peroneal nerve injury seen early after surgery. In the moderate nerve lesions, pain in the dorsal foot and ankle is seen as the symptom. The $t$ pain is rather 
considered as a post-operative pain. Therefore, electrophysiological studies are very important in order to define nerve lesions after HTO. On the other hand, early EMG and nerve conduction velocity studies are thought to give incorrect results due to edema, and a second investigation is recommended at least 6-months after the surgery. This in turn fails to define early lesions that recover in this period. The rate of peroneal nerve lesion was $27 \%$. However, he symptomatic patient rate was $9 \%$. This suggested that peroneal nerve lesions after HTO are more frequent than is reported (1).

Georgoulis et al. (4) investigated the possible causes of complications in the HTO operation in 23 cadaveric knee dissections, including arteries and nerves. The tibial nerve and popliteal artery were $0.5-1 \mathrm{~cm}$ behind the tibia at the osteotomy level. Popliteus and tibialis posterior muscles were located between the tibia and these neurovascular structures. A wrongly placed dispenser during surgery may compress the tibial nerve and popliteal artery. The tibialis anterior muscle is innervated by the $n$. peroneus profundus branch of the peroneal nerve. As $\mathrm{n}$. peroneus profundus passes through the proximity of fibular periosteum, there is the risk of injury. Branches innervating the extensor digitorum longus muscle are surrounded by muscles, thus the risk of injury is low. The same condition is present for the branches innervating peroneus longus and brevis muscles. Extensor hallucis longus muscle is innervated by two tiny and long nerve branches arising from the peroneus profundus. These are located at the tibial and fibular sides of the muscle. These branches are the longest muscular branches of peroneal nerve, and are located $10 \mathrm{~cm}$ distal to the fibular head. Nerve branch on the tibial side may be injured during retraction. However, this injury can be seen more often during insertion of the distal staple used for osteotomy fixation. Therefore, less invasive material (U-staple, semitubular plate) may solve this problem. The lateral cutaneous nerve, a branch of the superficial peroneal nerve, may be injured during distal fibular osteotomy (12 cm proximal to ankle or $16 \mathrm{~cm}$ distal to fibula). The nerve is mostly seen and protected by moving anteriorly (4).

Kirgis et al. (5) conducted a study on 29 cadavers and indicated important points related with the peroneal nerve and its branches. Cadaveric dissection showed that m.extensor hallucis is innervated by a single nerve in 16 cases and by 2 or more nerve branches in 13 cases. Measurements showed that the nerve branch innervating m.extensor hallucis arises $68-136 \mathrm{~mm}$ distal to the branching point of n.peronealis profundus in $91 \%$ of the cases. Therefore, the area 68 to $153 \mathrm{~mm}$ above the fibular head can be defined as a risk zone. The safe zone for fibular osteotomy may be defined as $16 \mathrm{~cm}$ distal to the fibular head.

Wildner et al. (6), studied the HTO operation in 182 patients and used U-staples for fixation except in four patients. 9 patients (4.9\%) had transient peroneal nerve palsy. Of these, 6 had motor deficits and 3 had sensory deficits (8).

Curley et al. (7) studied pre- and post-operative electrophysiologic parameters, creatine phosphokinase level, radiology and intracompartmental pressure in 16 patients who underwent HTO. Pre-operative electrophysiologic investigation revealed mild lesions in 12 patients. In terms of peroneal nerve involvement, scoring was made as 0-1-2-3 ( $0=$ normal, $3=$ the highest lesion).
The mean pre-operative score was $3.0 \pm 0.87$ and post-operative score was $8.8 \pm 2.17$ in patients who underwent proximal fibular osteotomy. This difference was significant $(p<0.05)$. On the other hand, in patients without proximal fibular osteotomy, the mean pre-operative score was $5.5 \pm 1.61$ and post-operative score was $5.2 \pm 1.65$. As seen, fibular osteotomy can be considered as a risky intervention for peroneal nerve injury. Hpwever, the importance of the fibular osteotomy site should be kept in mind (2).

Gibson et al. (8) studied HTO in 20 patients and measured anterior and deep posterior compartment pressures after closing the skin and before applying a plaster cast. Anterior compartment pressure of the other leg served as control. Half of the patients used a drain and the remaining half did not. In the group without a drain, anterior compartment pressure significantly increased in 7 patients $(>45 \mathrm{mmHg}$ ) and 5 of these patients had transient nerve lesions defined clinically. Only one patient had persistent weakness of the extensor hallucis longus muscle. In the group with a drain, compartment pressures did not increase except in 2 patients. These 2 patients showed no nerve lesion during the early period. However, ankle dorsiflexion was weak in the late period which was explained by late peroneal nerve palsy. The reason for the increase in compartment pressure was considered to be bleeding, but fibular intervention was ignored in the paper because some of the patients had distal fibular osteotomy whereas others had partial excision of the fibular head (6).

Elgafy et al. (2) investigated m.extensor hallucis longus innervation in 30 cadaveric legs. The muscle was innervated by only one branch of $\mathrm{N}$. peroneus profundus in $27(90 \%)$ legs, and by 2 branches in 3 (10\%) legs. The insertion point of N. peroneus profundus into the muscle was fibular in 21 legs, tibial in 6 legs and anterior in 6 legs. The nerve of the fibular side was very close to the fibular periosteum. The most risky zone for iatrogenic nerve injury was $5.9 \pm 1.7$ $\mathrm{cm}$ from the fibular head and $10.9 \pm 1.7 \mathrm{~cm}$ distal (3).

\section{CONCLUSION}

Based on our results, patients who had HTO using the closed wedge valgization technique showed the risk of injury to $N$. peroneus superficialis and $N$. peroneus profundus (branches of $N$. peroneus communis) during fibular osteotomy. This was based on amplitude reduction in the n. peroneus superficialis conduction velocity study and lesions identified during needle EMG study.

Ethics Committee Approval: Ethics committee approval was not received due to the retrospective nature of the study.

Informed Consent: Written informed consent was obtained from patients who participated in this study.

Peer-review: Externally peer-reviewed.

Author Contributions: Concept - B.Y., R.E., H.M.; Design - B.K., Ö.Ö.; Supervision - B.K., B.Y.; Funding - S.M., Ö.Ö.; Materials - B.Y., Ö.Ö., R.E.; Data Collection and/or Processing - B.Y., Ö.Ö., R.E.; Analysis and/or Interpretation - B.Y., S.M., H.M.; Literature Review - B.Y., S.M., H.M.; Writing - B.Y., S.M., H.M.; Critical Review - B.K., B.Y.; Other - B.K., S.M., H.M.

Conflict of Interest: No conflict of interest was declared by the authors.

Financial Disclosure: The authors declared that this study has received no financial support. 
Etik Komite Onayı: Çalışmanın retrospektif tasarımından dolayı etik kurul onayı alınmamıştır.

Hasta Onamı: Yazılı hasta onamı bu çalışmaya katılan hastalardan alınmıştır.

Hakem Değerlendirmesi: Dış bağımsız.

Yazar Katkıları: Fikir - B.Y., R.E., H.M.; Tasarım - B.K., Ö.Ö.; Denetleme - B.K., B.Y.; Kaynaklar - S.M., Ö.Ö.; Malzemeler - B.Y., Ö.Ö., R.E.; Veri toplanması ve/veya işlemesi - B.Y., Ö.Ö., R.E.; Analiz ve/veya yorum - B.Y., S.M., H.M.; Literatür taraması - B.Y., S.M., H.M.; Yazıyı yazan - B.Y., S.M., H.M.; Eleştirel İnceleme - B.K., B.Y.; Diğer - B.K., S.M., H.M.

Çıkar Çatışması: Yazarlar çıkar çatışması bildirmemişlerdir.

Finansal Destek: Yazarlar bu çalışma için finansal destek almadıklarını beyan etmişlerdir.

\section{REFERENCES}

1. Aydogdu S, Cullu E, Araç N, Varolgüneş N, Sur H. Prolonged peroneal nerve dysfunction after high tibial osteotomy: pre- and postoperative electrophysiological study. Knee Surg Sports Traumatol Arthrosc 2000; 8: 305-8. [CrossRef]

2. Elgafy H, Ebraheim NA, Shaheen PE, Yeasting RA. Extensor hallucis longus innervation: an anatomic study. Clin Orthop Relat Res. 2002: 245-51. [CrossRef]
3. Nebelung W, Wissel H, Awiszus F. On the applicability of two different stimulation techniques for intra-operative peroneal nerve conduction testing. J Orthop Res. 2001; 19: 160-5. [CrossRef]

4. Georgoulis AD, Makris CA, Papageorgiou CD, Moebius UG, Xenakis T, Soucacos PN. Nerve and vessel injuries during high tibial osteotomy combined with distal fibular osteotomy: a clinically relevant anatomic study. Knee Surg Sports Traumatol Arthrosc 1999; 7: 15-9. [CrossRef]

5. Kirgis A, Albrecht S. Palsy of the deep peroneal nerve after proximal tibial osteotomy. An anatomical study. J Bone Joint Surg Am. 1992; 74: 1180-5.

6. Wildner M, Peters A, Hellich J, Reichelt A. Complications of high tibial osteotomy and internal fixation with staples. Arch Orthop Trauma Surg 1992; 111: 210-2. [CrossRef]

7. Curley P, Eyres K, Brezinova V, Allen M, Chan R, Barnes M. Common peroneal nerve dysfunction after high tibial osteotomy. J Bone Joint Surg Br 1990; 72: 405-8.

8. Gibson MJ, Barnes MR, Allen MJ, Chan RN.Weakness of foot dorsiflexion and changes in compartment pressures after tibial osteotomy. J Bone Joint Surg Br 1986; 68: 471-5. 